Article

\title{
Discovery of Natural Dimeric Naphthopyrones as Potential Cytotoxic Agents through ROS-Mediated Apoptotic Pathway
}

\author{
Kuo Xu ${ }^{1,+}\left(\mathbb{D}\right.$, Chuanlong Guo ${ }^{1,2, \dagger}$, Jie Meng ${ }^{1,3} \mathbb{C}^{\text {, Haiying Tian }}{ }^{4}$, Shuju Guo ${ }^{1, *}$ \\ and Dayong Shi ${ }^{1,5, *}$ \\ 1 Chinese Academy of Sciences Key Laboratory of Experimental Marine Biology, Institute of Oceanology, \\ Chinese Academy of Sciences, Qingdao 266071, China; xukuoworld@126.com (K.X.); \\ gcl_cpu@126.com (C.G.); mengjie@qibebt.ac.cn (J.M.) \\ 2 Department of Pharmacy, College of Chemical Engineering, Qingdao University of Science and Technology, \\ Qingdao 266042, China \\ 3 College of Resources and Environment, Qingdao Agricultural University, Qingdao 266109, China \\ 4 Technology Center, China Tobacco Henan Industrial Co., Ltd., Zhengzhou, 450000, China; \\ 13623810925@126.com \\ 5 State Key Laboratory of Microbial Technology, School of Life Science, Shandong University, No. 72 Binhai \\ Road, Qingdao 266237, China \\ * Correspondence: guoshuju@qdio.ac.cn (S.G.); shidayong@qdio.ac.cn (D.S.); Tel.: +86-532-82898741 (S.G.); \\ +86-532-82898719 (D.S.) \\ + These authors contributed equally to this work.
}

Received: 11 March 2019; Accepted: 28 March 2019; Published: 2 April 2019

check for updates

\begin{abstract}
A study on the secondary metabolites of Aspergillus sp. XNM-4, which was derived from marine algae Leathesia nana (Chordariaceae), led to the identification of one previously undescribed (1) and seventeen known compounds (2-18). Their planar structures were established by extensive spectroscopic analyses, while the stereochemical assignments were defined by electronic circular dichroism (ECD) calculations. The biological activities of the compounds were assessed on five human cancer cell lines (PANC-1, A549, MDA-MB-231, Caco-2, and SK-OV-3), and one human normal cell line (HL-7702) using an MTT [3-(4,5-dimethyl-2-thiazolyl)-2,5-diphenyl tetrazolium bromide] assay. Among them, the dimeric naphthopyrones 7, 10 and 12 exhibited potent cytotoxicity. Further mechanism studies showed that $\mathbf{1 2}$ induced apoptosis, arrested the cell cycle at the G0/G1 phase in the PANC-1 cells, caused morphological changes and generated ROS; and it induces PANC-1 cells apoptosis via ROS-mediated PI3K/Akt signaling pathway.
\end{abstract}

Keywords: Aspergillus; naphthopyrones; cytotoxicity; endophytic fungus; Leathesia nana

\section{Introduction}

Marine-derived endophytic fungi have drawn considerable attention for their surprising potential in drug discovery [1-5]. These endophytic fungi can be distributed in every possible marine host, such as plants, invertebrates and vertebrates [6]. In the interactional process of symbiosis and evolution, the host provides suitable living conditions to the endophytes, while the endophytes contribute bioactive secondary metabolites that provide protection and, ultimately, survival value to their hosts $[7,8]$. As one of the most prevalent sources of microorganisms, marine algae offer an abundant amount of endophytic fungi for chemical studies. Hundreds of natural products have been identified from the algal-derived fungi [9].

In our ongoing efforts to discover the bioactive secondary metabolites of endophytic fungi from the marine brown algae Leathesia nana (Chordariaceae), eighteen compounds were isolated 
from an Aspergillus sp. XNM-4 strain (Figure 1). The planar structures of the metabolites were established by HRESIMS, UV, IR, one- and two-dimensional (1D and 2D) NMR spectroscopic data, while the stereochemistry of compounds 1 and $\mathbf{1 2}$ were assigned by a comparison of the calculated and experimental electronic circular dichroism (ECD). All compounds were assessed for inhibitory effects on five human cancer cell lines (PANC-1, A549, MDA-MB-231, Caco-2, and SK-OV-3) and one human normal cell line (HL-7702). Notably, as the most promising candidate, the cytotoxic mechanism of compound 12 in PANC-1 cells was studied preliminarily. These experimental results may be beneficial for the development of naturally occurring dimeric naphthopyrones as anti-tumor agents.
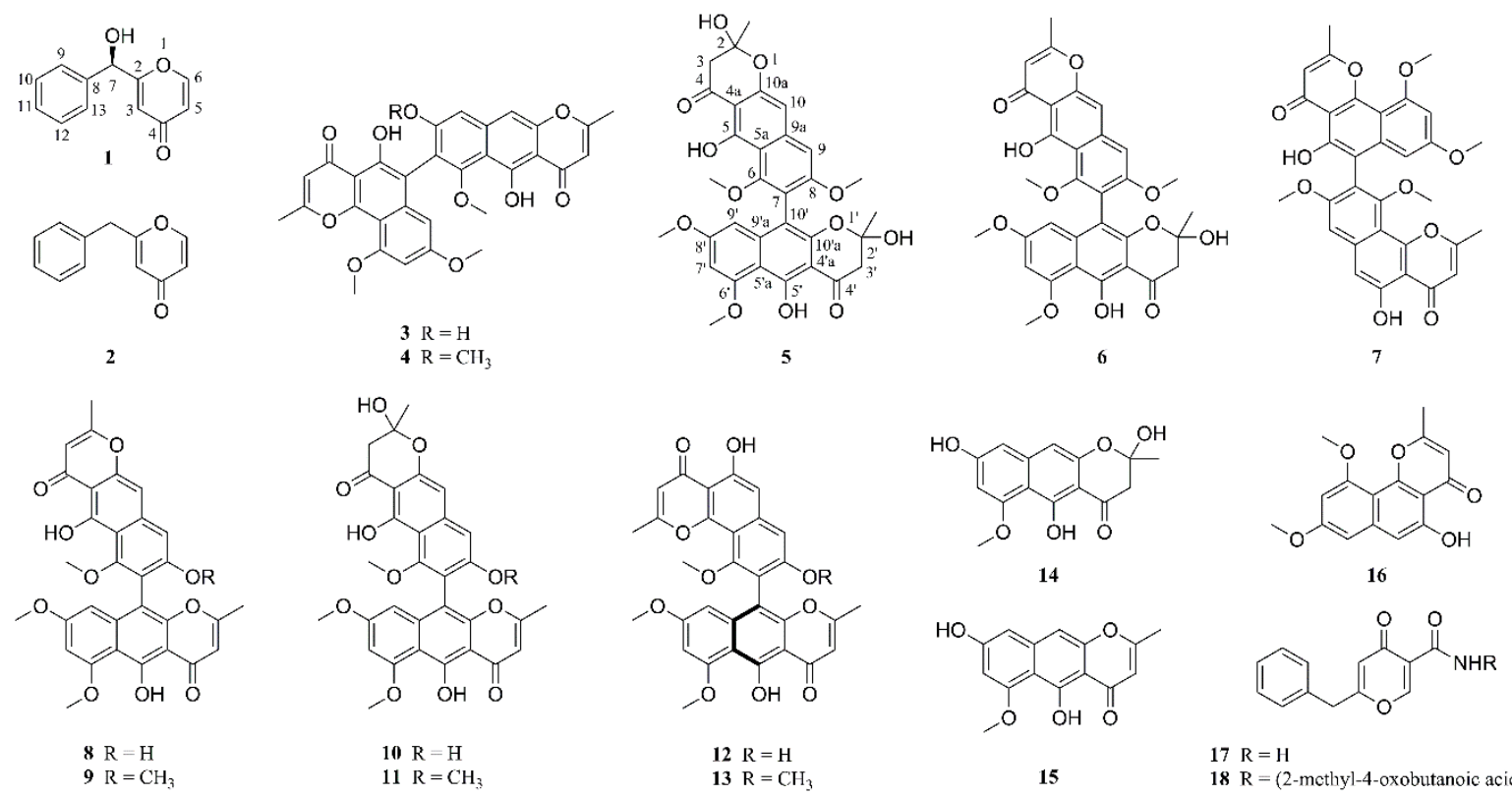

Figure 1. Compounds 1-18 isolated from Aspergillus sp. XNM-4.

\section{Results and Discussion}

\subsection{Structural Elucidation}

Compound 1 was isolated as a white amorphous powder. Its molecular formula $\left(\mathrm{C}_{12} \mathrm{H}_{10} \mathrm{O}_{3}\right)$ was determined on the HRESIMS $\left(\mathrm{m} / \mathrm{z} 203.0707[\mathrm{M}+\mathrm{H}]^{+}\right.$, calcd 203.0708, Figure S3) in association with ${ }^{13} \mathrm{C}$ NMR data. The IR spectrum (Figure S4) exhibited absorption bands for carbonyl $\left(1653 \mathrm{~cm}^{-1}\right)$ and olefinic $\left(1384,1602 \mathrm{~cm}^{-1}\right)$ groups. The ${ }^{1} \mathrm{H}$ NMR data of $\mathbf{1}$ (Table 1, Figure S5) revealed an ABX spin-system assignable to three pyrone protons $\left[\delta_{\mathrm{H}} 8.05\left({ }^{1} \mathrm{H}, \mathrm{d}, J=6.0 \mathrm{~Hz}\right), 6.21\left({ }^{1} \mathrm{H}, \mathrm{dd}, J=2.4\right.\right.$, $6.0 \mathrm{~Hz})$, and $\left.6.42\left({ }^{1} \mathrm{H}, \mathrm{d}, J=2.4 \mathrm{~Hz}\right)\right]$; however, their coupling constants were different from those of the benzene ring. The ${ }^{1} \mathrm{H}$ NMR spectrum also showed five pyrone protons $\left[\delta_{\mathrm{H}} 7.41(2 \mathrm{H}\right.$, overlap), $7.37(2 \mathrm{H}$, overlap), and $\left.7.32\left({ }^{1} \mathrm{H}, \mathrm{m}\right)\right]$ and an oxygenated methyne $\delta_{\mathrm{H}} 5.48\left({ }^{1} \mathrm{H}, \mathrm{s}\right)$. In combination with the five resonance peaks at $\delta_{\mathrm{H}} 7.32-7.41$, the pyrone resonances in the ${ }^{13} \mathrm{C}$ NMR spectrum $\left[\delta_{\mathrm{C}} 140.6(1 \mathrm{C}), 128.4\right.$ (2C), 128.0 (1C), and 126.8 (2C), Figure S6] supported the existence of a mono-substituted benzene ring [10]. The remaining five resonance peaks [ $\delta_{C} 177.9(1 C), 170.2(1 C), 156.2(1 C), 116.2(1 C)$, and $112.3(1 \mathrm{C})]$ indicated a skeleton of $4 \mathrm{H}$-pyran-4-one [11], except for the oxygenated carbon resonance at $\delta_{\mathrm{C}} 71.2(1 \mathrm{C})$. In the 2D NMR experiment (Figures S7 and S8), the hydrogen resonance at $\delta_{\mathrm{H}} 6.21(\mathrm{H}-5)$ has a homonuclear correlation with the resonance at $\delta_{\mathrm{H}} 8.05(\mathrm{H}-6)$, and the hydrogen resonance at $\delta_{\mathrm{H}}$ $5.48(\mathrm{H}-7)$ has long-range heteronuclear correlations with the carbon resonances at $\delta_{\mathrm{C}} 112.3(\mathrm{C}-3)$ and 126.8 (C-9, 13), which confirmed that a benzyl group was substituted at C-2. Thus, the structure of compound 1 was identified as (hydroxy(phenyl)methyl)-4H-pyran-4-one. 
Table 1. ${ }^{1} \mathrm{H},{ }^{13} \mathrm{C}$ NMR and HMBC spectroscopic data of $\mathbf{1}\left(600 \mathrm{MHz}, \mathrm{ppm}\right.$ in DMSO- $\left.d_{6}\right)$.

\begin{tabular}{cccc}
\hline Position & $\delta_{\mathbf{H}}(J$ in $\mathbf{H z})$ & $\delta_{\mathbf{C}}(\mathbf{m})$ & Key HMBC $(\mathrm{H} \rightarrow \mathrm{C})$ \\
\hline 2 & & 170.2 & \\
3 & $6.42, \mathrm{~d}(J=2.4)$ & 112.3 & $\mathrm{C}-5,7$ \\
4 & & 177.9 & \\
5 & $6.21, \mathrm{dd}(J=2.4,6.0)$ & 116.2 & $\mathrm{C}-3$ \\
6 & $8.05, \mathrm{~d}(J=6.0)$ & 156.2 & $\mathrm{C}-4$ \\
7 & $5.48, \mathrm{~s}$ & 71.2 & $\mathrm{C}-3,9,13$ \\
8 & & 140.6 & \\
9 & 7.37, overlap & 126.8 & $\mathrm{C}-7,11$ \\
10 & 7.41, overlap & 128.4 & $\mathrm{C}-8$ \\
11 & $7.32, \mathrm{~m}$ & 128.0 & $\mathrm{C}-9,13$ \\
12 & 7.41, overlap & 128.4 & $\mathrm{C}-8$ \\
13 & 7.37, overlap & 126.8 & $\mathrm{C}-7,11$ \\
\hline
\end{tabular}

The configurational assignment of C-7 was defined by ECD calculations using a MMFF94 force field and time-dependent density functional theory (TDDFT) at the B3LYP/6-311+G(d, p) level. The overall calculated ECD curve of (7R)-1 were produced by Boltzmann weighting of their lowest energy conformers, matching well with the corresponding experimental ECD data (Figure 2, the procedure was detailed in Supplementary Materials, S34-S36). Thus, the structure of compound 1 was finally established as (7R)-(hydroxy(phenyl)methyl)-4H-pyran-4-one.

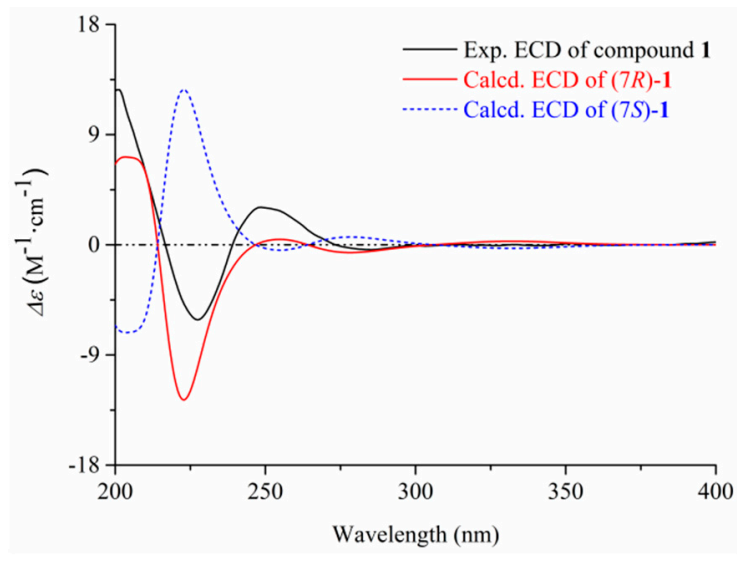

(a)

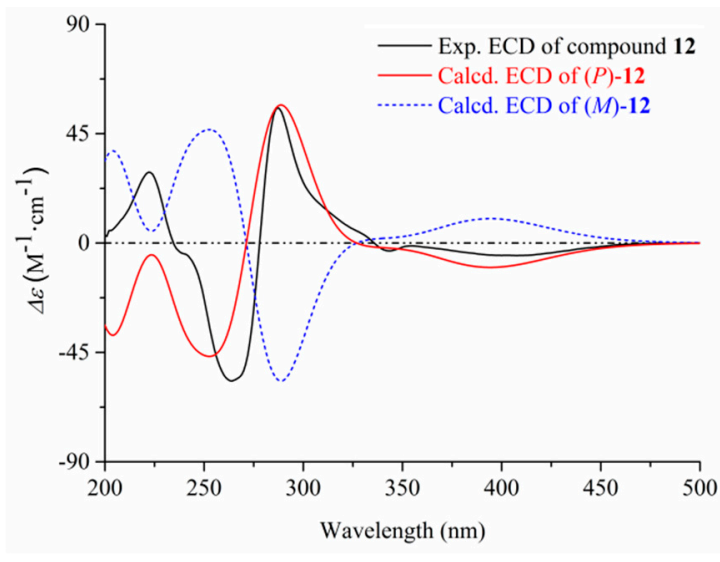

(b)

Figure 2. The experimental and calculated ECD of compounds $\mathbf{1}(\mathbf{a})$ and $\mathbf{1 2}(\mathbf{b})$.

By comparing the spectroscopic data (HRESIMS, ${ }^{1} \mathrm{H}$ and ${ }^{13} \mathrm{C}$ NMR, Figures S9-S60) with those reported in the literature, the remaining nineteen known compounds (2-21) were identified as 2-benzyl-4H-pyran-4-one (2) [11], asperpyrone D (3) [12], asperpyrone C (4) [13], aurosperone B (5) [14], fonsecinone B (6) [14], asperpyrone B (7) [15], dianhydro-aurasperone C (8) [12], isoaurasperone A (9) [15], aurasperone F (10) [16], fonsecinone D (11) [14], asperpyrone A (12) [12], fonsecinone A (13) [15], fonsecin (14) [14], TMC 256 A1 (15) [17], flavasperone (16) [14], carbonarone A (17) [18], pestalamide A (18) [19]. In addition, the $p$ configuration of 12 was defined by ECD calculation at the B3LYP/6-311+G(d, p) level (Figure 2, Supplementary Materials, S34-36).

\subsection{Cytotoxic Activities of Compounds $\mathbf{1} \mathbf{- 1 8}$}

Natural naphthopyrones have been previously reported for their anticancer potential $[13,15,17]$. Therefore, the present study evaluated the inhibitory effects of the isolated compounds on five human cancer cell lines (PANC-1, A549, MDA-MB-231, Caco-2, and SK-OV-3), and one human normal cell line (HL-7702) at a concentration of $50 \mu \mathrm{M}$. As a result, the dimeric naphthopyrones 7, 10, and 
especially 12, exhibited potent cytotoxicity on PANC-1, A549, MDA-MB-231, Caco-2, SK-OV-3 and HL-7702 cells (Figure 3). The $\mathrm{IC}_{50}$ values of compound 12 on the different cells were further measured, and it possessed the greatest inhibitory effects against PANC-1, with an $\mathrm{IC}_{50}$ value of $8.25 \pm 2.20 \mu \mathrm{M}$ (Figure 4A).

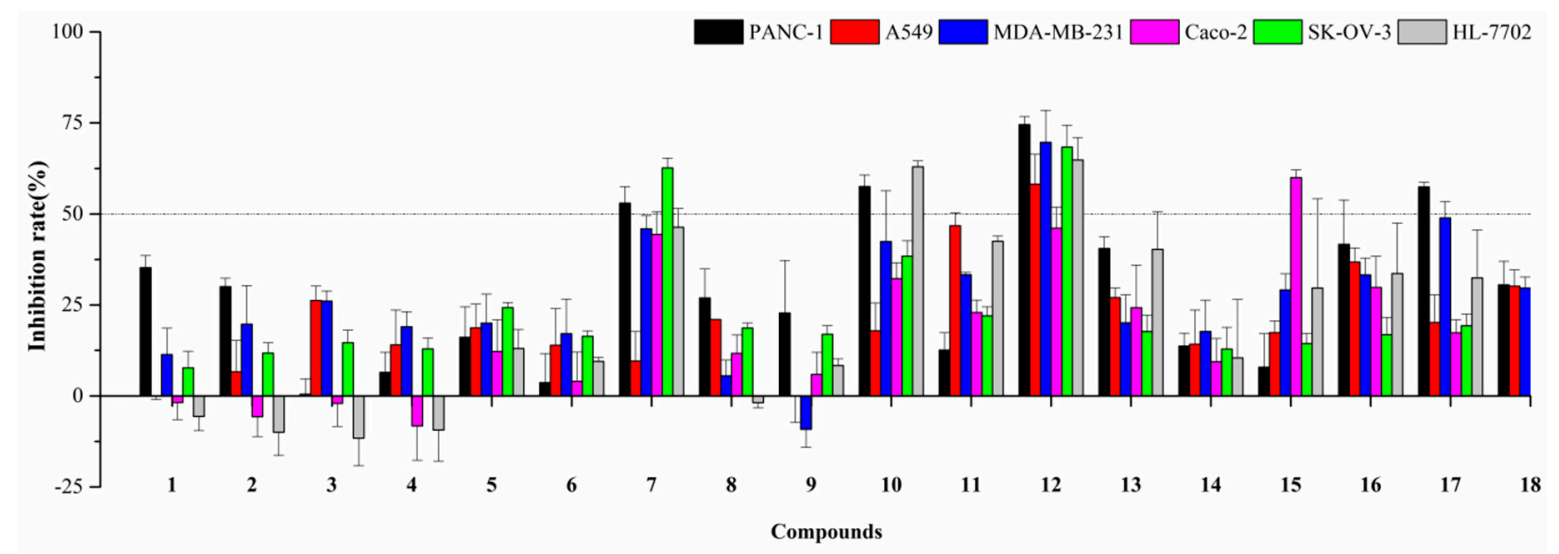

Figure 3. Cytotoxic activities of compounds 1-18 at the concentration of $50 \mu \mathrm{M}$.

A

C

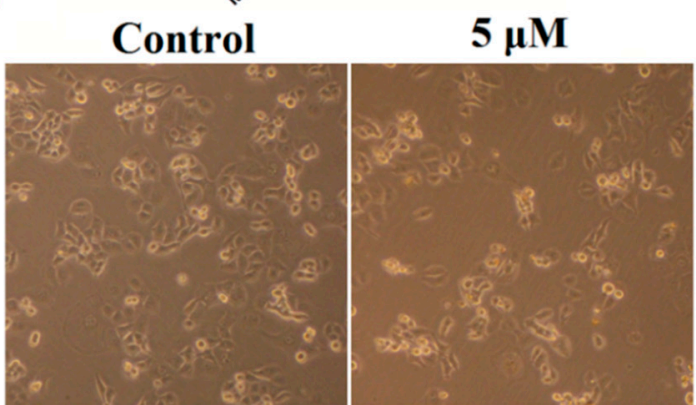

B

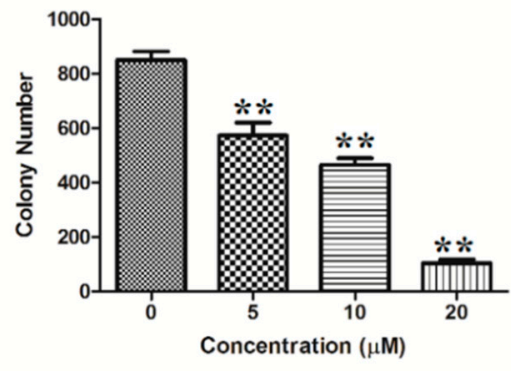

$10 \mu \mathrm{M}$

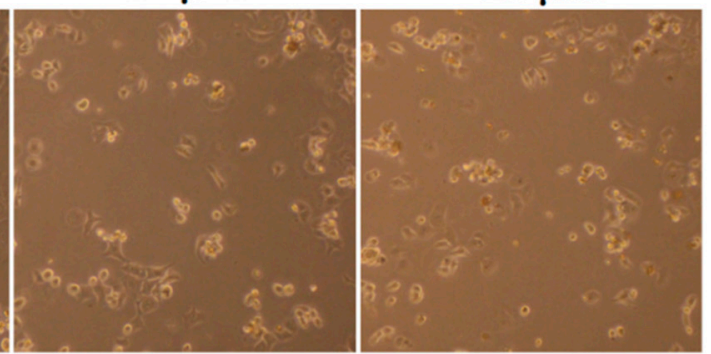

Figure 4. (A) The $\mathrm{IC}_{50}$ values of compound 12 on PANC-1, A549, MDA-MB-231, Caco-2, SK-OV-3, and HL-7702 cells; (B) colony formation in PANC-1 cells was determined by staining with crystal violet;

(C) cell morphology was observed using inverted microscope. ${ }^{* *} p<0.01$ vs. control group.

\subsection{Pharmacological Mechanism of Compound 12 on PANC-1 Cells}

\subsubsection{Morphological Changes}

It is well known that cytotoxic agents often cause changes in cell morphology, such as irregular cell morphology, increased cell debris, and reduced cell numbers. As shown in Figure 4, after treatment with compound 12, the PANC-1 cells showed morphological changes such as cell shrinkage, deformation and a reduced number of viable cells.

\subsubsection{Colony Formation}

A 10-day colony formation experiment was performed to explore the long-term impact of compound 12 on the PANC-1 cells growth. PANC-1 cells were seeded in 6-well plates (1000 cells/well) 
and were treated with various concentrations of compound $12(0,5,10,20 \mu \mathrm{M})$ for 10 days to allow colony formation. As shown in Figure 4B, $852 \pm 43$ colonies were present in the control group, whereas the colony numbers decreased to $574 \pm 65,421 \pm 30$ and $105 \pm 21$ after treatment with compound 12 $(5,10$, and $20 \mu \mathrm{M}$, respectively). These results showed that compound $\mathbf{1 2}$ could inhibit the colony formation of PANC-1 cells.

\subsubsection{Cell Apoptosis}

To explore whether the abovementioned reduction in cell viability was caused by the induction of apoptosis, PANC-1 cells were treated with compound $12(5,10$, and $20 \mu \mathrm{M})$ for $72 \mathrm{~h}$. The cells were then stained with fluorescein isothiocyanate (Annexin-V FITC) and propidium iodide (PI) and were analyzed by flow cytometry. The results indicated that compound $\mathbf{1 2}$ could induce cell apoptosis in a concentration-dependent manner. As shown in Figure $5 \mathrm{~A}, \mathrm{~B}, 11.07 \pm 2.43 \%$ of the apoptotic cells were present in the control, whereas the apoptotic population increased to $19.93 \pm 65,26.43 \pm 3.81$ and $40.43 \pm 3.27$ after treatment with $\mathbf{1 2}(5,10$, and $20 \mu \mathrm{M}$, respectively).
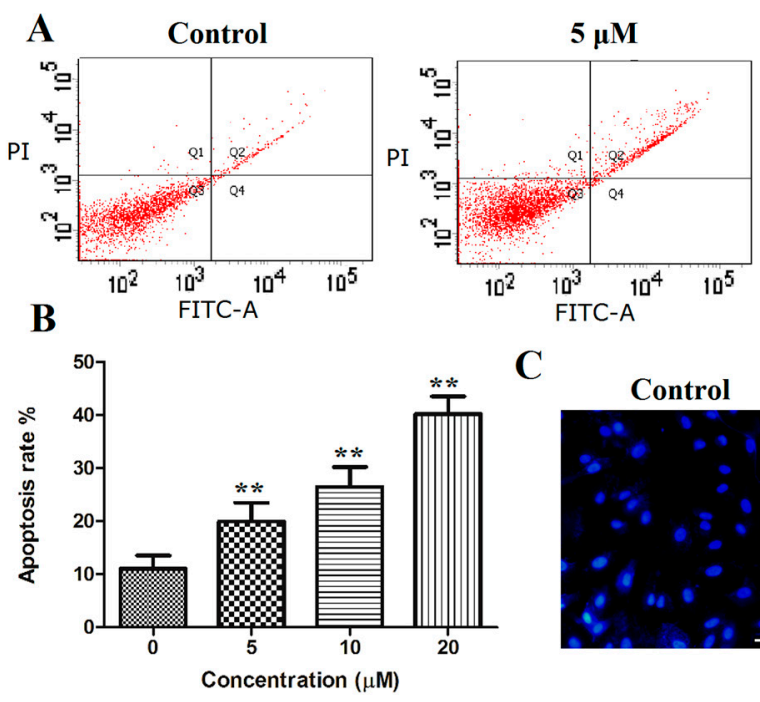

C

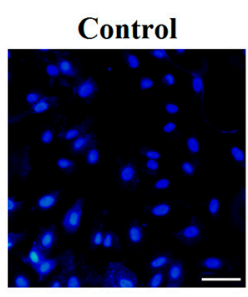

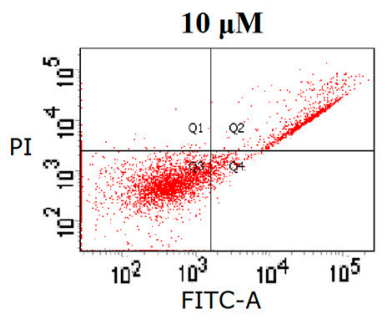
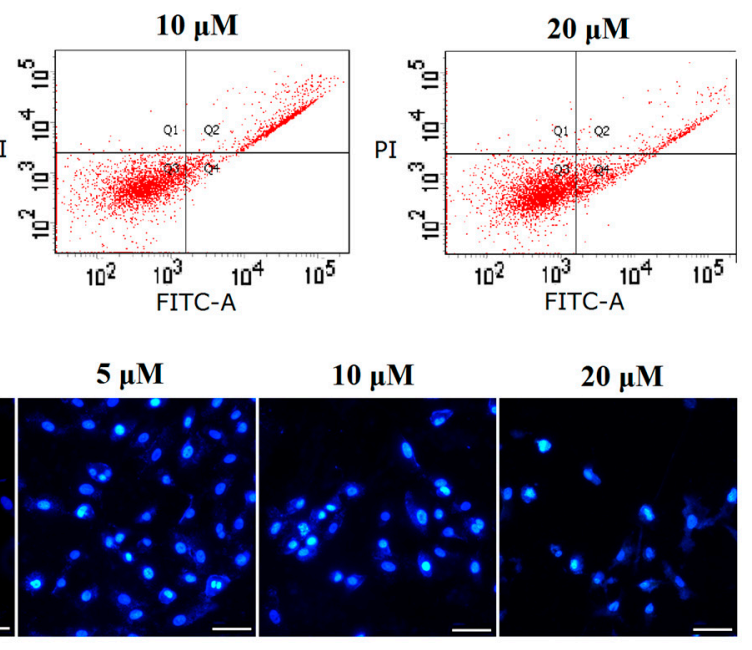

Figure 5. (A,B) PANC-1 cells were stained with Annexin-V FITC and propidium iodide (PI), and then analyzed using flow cytometry, both early and late apoptotic cells were analyzed; (C) PANC-1 cells were stained with Hoechst 33258 and photographed using a fluorescence microscopy (bar $=50 \mu \mathrm{m})$. ** $p<0.01$ vs. control group.

Apoptosis often causes morphological changes, which can be observed by Hoechst 33258 staining the apoptotic cells. Thus, the PANC-1 cells were treated with compound $12(5,10$, and $20 \mu \mathrm{M})$ for $72 \mathrm{~h}$, stained with Hoechst 33258 and analyzed by fluorescence microscopy; significant morphological changes were observed. As shown in Figure 5C, nuclear pyknosis and chromosome condensation were observed in PANC-1 treated with compound 12, and no apoptosis was found in the control group.

\subsubsection{Cell Cycle}

To explore the influence of this compound on the cell cycle distribution, PANC-1 cells were treated with compound $12(5,10$, and $20 \mu \mathrm{M})$ for $72 \mathrm{~h}$. Next, the cell cycle distribution was analyzed by flow cytometry after staining with PI. As shown in Figure 6A,B, the G0/G1 phase was increased in a concentration-dependent manner in the PANC-1 cells. Compared with the control group, the population in the G1 phase increased from $45.97 \%$ to $70.94 \%$ at a concentration of $20 \mu \mathrm{M}$. Moreover, the sub-G1 group significantly increased after the cells were cultured with compound $\mathbf{1 2}$ (Figure 6C). These results indicated that compound $\mathbf{1 2}$ could induce apoptosis and arrested the cell cycle at the G0/G1 phase in PANC-1 cells in a concentration-dependent manner. 

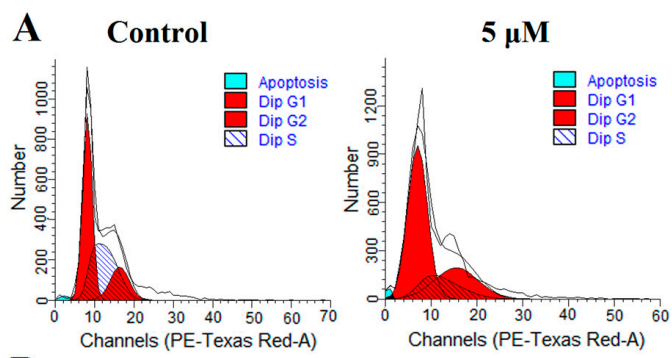

B

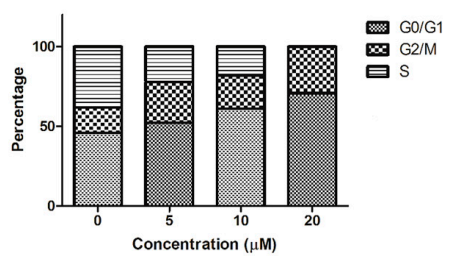

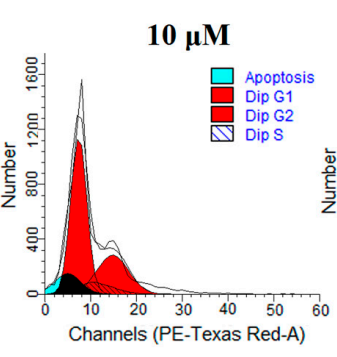

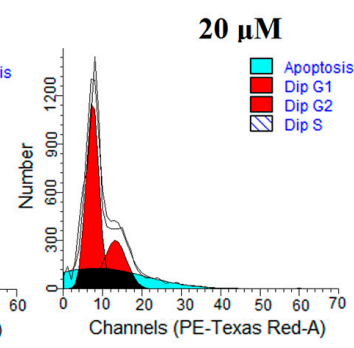

C

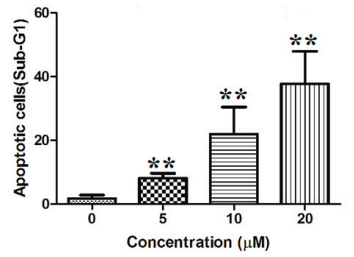

Figure 6. (A) PANC-1 cells were stained with propidium iodide (PI) and analyzed using flow cytometry; (B) proportion of PANC-1 cells in each phase; (C) the sub-G1 was increased after treatment of compound

12. ${ }^{* *} p<0.01$ vs. control group.

\subsubsection{ROS Generation}

ROS (reactive oxygen species) plays an important role in cell proliferation or apoptosis [20,21], and it can induce cell death in a variety of ways. When intracellular ROS accumulates in cells, it causes the mitochondrial membrane potential damage and eventually leads to apoptosis [22,23]. To explore whether this compound triggers ROS generation, PANC-1 cells were stained with a fluorescent probe, $2^{\prime}, 7^{\prime}$-dichlorodihydrofluorescein in diacetate (DCFH-DA), which can detect intracellular ROS. The result showed that a rapid production of ROS could be detected in the PANC-1 cells after the treatment of compound 12. As shown in Figure 7A,B, compared with that of the control, the ROS content in the experimental group increased to $120.09 \%, 336.99 \%$ and $449.09 \%$. The ROS-mediated effects may be modulated by antioxidants such as $N$-acetylcysteine (NAC). Next, PANC-1 cells were treated with $10 \mu \mathrm{M}$ compound 12 combined with/without 5 mM NAC (Beyotime, Nanjing, China), a ROS scavenger, for $72 \mathrm{~h}$, cells were harvested and analyzed after staining with DCFH-DA. The results showed that compound 12-induced ROS generation was blocked by NAC in PANC-1 cells (Figure 7C). These data indicated that compound $\mathbf{1 2}$ could induce ROS generation, and this might be a mechanism of apoptosis.
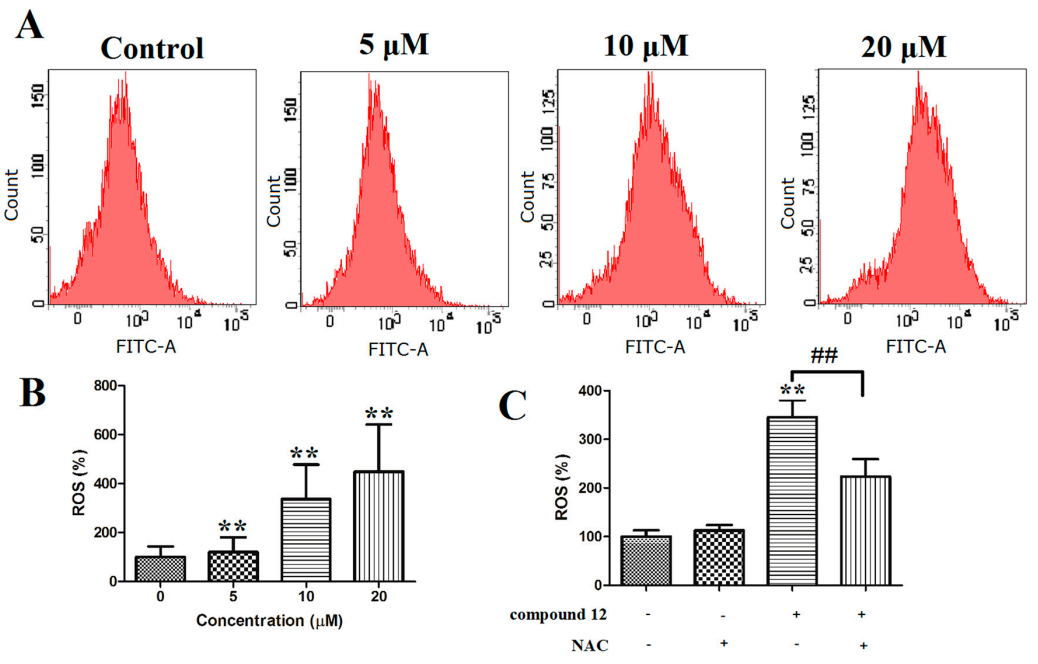

Figure 7. (A,B) PANC-1 cells were stained with $2^{\prime}, 7^{\prime}$-dichlorodihydrofluorescein in diacetate (DCFH-DA) and then analyzed using flow cytometry; (C) PANC-1 cells were treated with $10 \mu \mathrm{M}$ compound 12 alone or in combination with NAC $(5 \mathrm{mM})$ for $72 \mathrm{~h}$. ${ }^{* *} p<0.01 \mathrm{vs.} \mathrm{control} \mathrm{group.}$ \#\# $p<0.01$ vs. compound $12(+) / \mathrm{NAC}(-)$ group. 


\subsubsection{Mechanism Study of Compound 12}

Apoptosis serves a key role in the regulation of cells. It mainly comprised two apoptotic pathways: The death receptor-mediated apoptosis pathway and the mitochondria-mediated apoptosis pathway [24]. In the mitochondria-mediated apoptosis pathway, proteins from the Bcl-2 family, such as Bax and $\mathrm{Bcl}-2$, are the main components that regulate mitochondrial permeability [25]. In this study, it was demonstrated that compound 12 treatment could increase the ratio of Bax/Bcl-2 as well as activate Caspase-3 and PARP (Figure 8A).
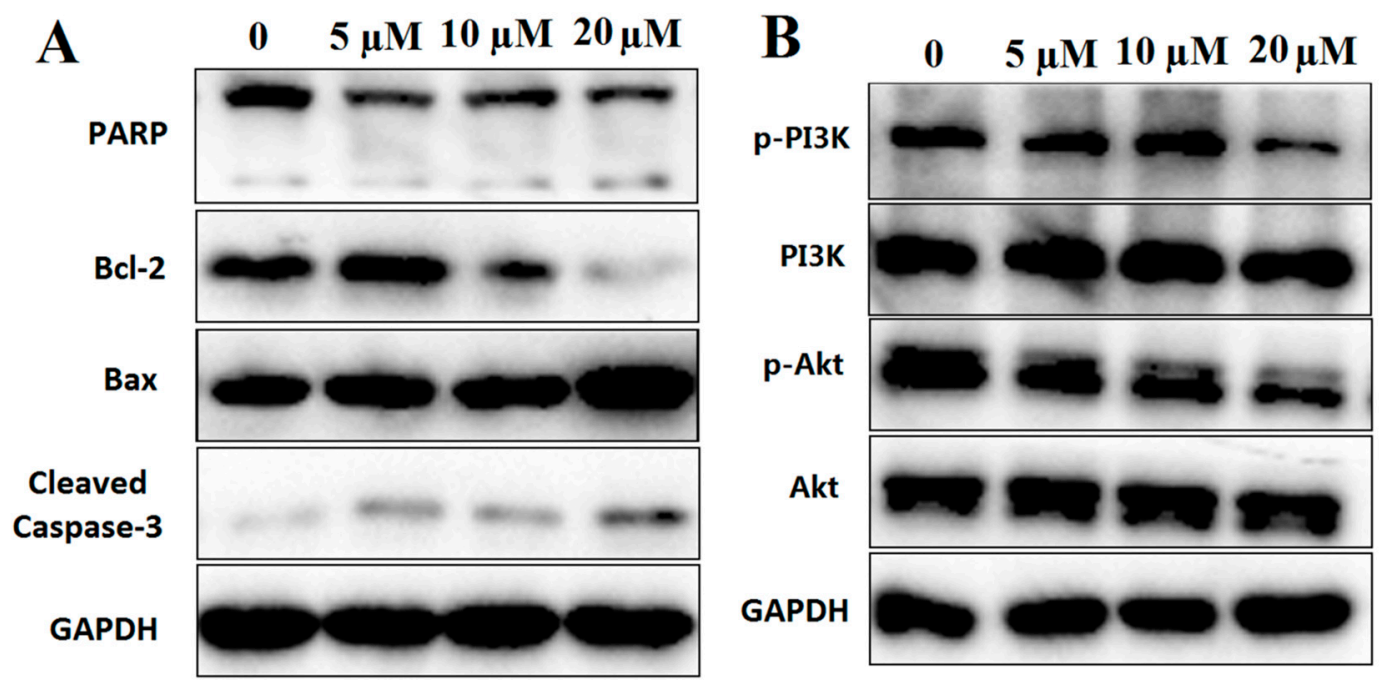

Figure 8. (A) Western blot analysis of apoptosis-related proteins, including PARP, Bcl-2, Bax and Cleaved-Caspase-3; (B) western blot analysis of PI3K/Akt pathway proteins, including PI3K and Akt. GAPDH was used to normalize protein content $(n=3)$.

PI3K/Akt signaling pathway plays an important role in the process of apoptosis especially in the ROS-mediated apoptotic pathway [26,27]. In this study, the phosphorylation of PI3K and Akt were decreased after treatment with compound 12 (Figure $8 \mathrm{~B}$ ). Based on the above studies, our results indicated that compound 12-induced PANC-1 apoptosis may be through ROS-mediated PI3K/Akt signaling pathway.

\section{Materials and Methods}

\subsection{General Experimental Procedures}

The HRESIMS analyses were performed on a Waters Xevo G2-XS QTof mass spectrometer (Waters Corp., Milford Massachusetts, America). NMR spectra were recorded on an Ascend $600 \mathrm{MHz}$ instrument (Bruker-Biospin, Billerica, MA, America). The analytical experiments were performed on a Shimadzu LC-20AT HPLC system (Shimadzu Corp., Kyoto, Japan) equipped with a Shimadzu InertSustain C18 column (4.6 I.D. $\times 250$ mm, $5 \mu \mathrm{m}, \mathrm{S} / \mathrm{N}$ 6LR98081). A Hanbon NP700 semipreparative HPLC (Hanbon Sci. \& Tech., Jiangsu, China) equipped with a Shimadzu InertSustain C18 column (10 I.D. $\times 250 \mathrm{~mm}, 5 \mu \mathrm{m}, \mathrm{S} / \mathrm{N}$ 7ER43006) was used for purifying compounds. Biological assays were monitored on a BioTek ELx808 microplate spectrophotometer (BioTek Instruments, Inc., Winooski, America), a BD FACSCalibur flow cytometry (BD Biosciences, Franklin Lakes, America) and an Olympus BX-51 Fluorescence Microscopy (Olympus Corporation, Tokyo, Japan).

\subsection{Fungal Material and Fermentation}

The fungus strain Aspergillus sp. XNM-4 was isolated from Leathesia nana, which was collected in April 2017 in Weihai, Shandong Province, China (Latitude: $37^{\circ} 31^{\prime} 57.58^{\prime \prime} \mathrm{N}$; Longitude: $122^{\circ} 02^{\prime} 52.85^{\prime \prime} \mathrm{E}$ ). 
The strain was identified according to $18 \mathrm{~S}$ rDNA gene sequence analysis by the Beijing Genomics Institute (Shenzhen, China).

The fungus Aspergillus sp. XNM-4 was fermented on Malt Extract Medium $(130.0 \mathrm{~g} / \mathrm{L}$ malt extract, $0.1 \mathrm{~g} / \mathrm{L}$ chloramphenicol, $15.0 \mathrm{~g} / \mathrm{L}$ agar, $\mathrm{pH} 5.6 \pm 0.2)$ under static conditions at $25^{\circ} \mathrm{C}$ for 10 days. A total of 300 culture dishes $(90 * 15 \mathrm{~mm})$ were used in the experiment.

\subsection{Extraction and Isolation}

The agar blocks with mycelium were collected in a $2 \mathrm{~L}$ beaker, and ultrasonically extracted with $1.5 \mathrm{~L}$ of ethyl acetate (three times and for $30 \mathrm{~min}$ each). The crude extract $(10.3 \mathrm{~g})$ was chromatographed on a silica gel column $\left(4^{*} 40 \mathrm{~cm}, 200-300\right.$ mesh) and successively eluted with petroleum ether $(0.5 \mathrm{~L})$, petroleum-EtOAc (4:1, $2.5 \mathrm{~L})$, petroleum-EtOAc (1:2, 2 L), EtOAc (1 L), and EtOAc-MeOH (1:2, 2 L). The eluents were concentrated by reduced pressure at $40{ }^{\circ} \mathrm{C}$, and then merged in nine fractions under HPLC analysis, including Fractions A (985.5 mg), B (364.6 mg), C (41.7 mg), D (90.4 mg), E (220.2 mg), F (344.6 mg), G (384.7 mg), H (8.3 mg), and I (1611.4 mg). These subfractions were further purified by semipreparative HPLC using a continuous gradient of $\mathrm{MeOH}-\mathrm{H}_{2} \mathrm{O}(60-100 \%, 20 \mathrm{~min}, 3 \mathrm{~mL} / \mathrm{min})$. The obtained eluents were extracted by ethyl acetate $(\mathrm{v} / \mathrm{v}, 1: 2)$ twice. After being dried by anhydrous $\mathrm{Na}_{2} \mathrm{SO}_{4}$, the organic phase was concentrated under a reduced pressure at $40{ }^{\circ} \mathrm{C}$ and then freeze-dried to yield compounds 1-18. As a result, compounds $2(3.1 \mathrm{mg}), \mathbf{1 5}(5.2 \mathrm{mg})$, and $\mathbf{1 6}(4.4 \mathrm{mg})$ were from Fr. D, compounds 3 (3.0 mg), 4 (3.8 mg), 5 (9.2 mg), 6 (7.0 mg), 7 (5.3 mg), 9 (13.4 mg), 11 (4.2 mg), $13(8.9 \mathrm{mg})$, and $14(11.6 \mathrm{mg})$ were from Fr. E, compounds 8 (7.4 mg), $10(8.2 \mathrm{mg}), \mathbf{1 2}(8.8 \mathrm{mg})$, 17 (29.2 mg), 18 (5.4 mg) were from Fr. F, compound $\mathbf{1}(5.0 \mathrm{mg}$ ) was from Fr. G. The purities of all isolated compounds was determined to be $>95 \%$ under two solvent conditions by analytical HPLC recorded on a Shimadzu LC-20A system. Solvent conditions A: $\mathrm{CH}_{3} \mathrm{OH} / \mathrm{H}_{2} \mathrm{O}$ with $0.1 \%$ trifluoroacetic acid $60-100 \%$ (20 min); Solvent conditions B: $\mathrm{CH}_{3} \mathrm{CN} / \mathrm{H}_{2} \mathrm{O}$ with $0.1 \%$ trifluoroacetic acid $30-100 \%$ (20 min); UV detection, $254 \mathrm{~nm}$; flow rate, $1.0 \mathrm{~mL} / \mathrm{min}$; temperature, $40{ }^{\circ} \mathrm{C}$; injection volume, $30 \mu \mathrm{L}$. The analytical HPLC spectra were listed on page S37-S54 in the Supplementary Materials.

(7R)-(hydroxy(phenyl)methyl)-4H-pyran-4-one (1): white amorphous powder; $[\alpha]_{\mathrm{D}}^{20}+78.1^{\circ}($ c 0.10 , $\mathrm{MeOH}) ; \mathrm{UV}(\mathrm{MeOH}) \lambda_{\max }(\log \varepsilon) 248(4.14) \mathrm{nm} ; \mathrm{ECD}(\mathrm{MeOH}) \lambda_{\max }(\Delta \varepsilon) 201(+12.65), 228$ (-6.13), 250 (+3.01) nm; IR (KBr) $v_{\max } 3447,1653,1602,1384 \mathrm{~cm}^{-1}$; ${ }^{1} \mathrm{H}$; for ${ }^{13} \mathrm{C}$ NMR data see Table 1 ; HRESIMS (m/z): $203.0707[\mathrm{M}+\mathrm{H}]^{+}$(calcd for $\mathrm{C}_{12} \mathrm{H}_{11} \mathrm{O}_{3}, 203.0708$ ).

\subsection{Biological Activity Test}

\subsubsection{Cell Culture}

PANC-1, A549, MDA-MB-231, Caco-2, SK-OV-3 and HL-7702 were supplied by Cell Bank, Chinese Academy of Sciences (Shanghai, China). These cells were separately maintained in DMEM medium, F-12K medium, L15 medium, MEM medium, McCoy's 5A (Modified) medium, and RPMI-1640 medium. All media were supplemented with $10 \% \mathrm{FBS}, 100 \mathrm{U} / \mathrm{mL}$ penicillin and $100 \mu \mathrm{g} / \mathrm{mL}$ streptomycin. Cells were cultured at $37^{\circ} \mathrm{C}$ in a humidified $\mathrm{CO}_{2}(5 \%)$.

\subsubsection{Determination of Cell Viability}

Cell viability was evaluated by a 3-(4,5-dimethyl-2-thiazolyl)-2,5-diphenyl tetrazolium bromide (MTT) assay [28]. For the preliminary anti-tumor activity screening, the cells were plated in 96-well plates $\left(3 \times 10^{3}\right.$ cells/well for A549 and PANC-1, A549, MDA-MB-231 and Caco-2, $5 \times 10^{3}$ cells/well for SK-OV-3 and GL-7702) and incubated with the tested compounds at a concentration of $50 \mu \mathrm{M}$ for $72 \mathrm{~h}$. For detection of the $\mathrm{IC}_{50}$, cells were treated with varying concentrations of $\mathbf{1 2}(0,6.25,12.5,25,50 \mu \mathrm{M})$ for $72 \mathrm{~h}$. After incubation, MTT $(5 \mathrm{mg} / \mathrm{mL})$ was added and incubated at $37^{\circ} \mathrm{C}$ for $4 \mathrm{~h}$. The formazan was dissolved by DMSO and measured using a microplate reader at $490 \mathrm{~nm}$. 


\subsubsection{Colony Forming Assay}

The PANC-1 cells were seeded in 6-well plates (1000 cells/well) and treated with varying concentrations of $\mathbf{1 2}(0,5,10,20 \mu \mathrm{M})$. These cells were further incubated for 10 days to allow colony formation; then, the cells were fixed with $4 \%$ paraformaldehyde for $10 \mathrm{~min}$. After three washes, the cells were finally stained with crystal violet for $10 \mathrm{~min}$. Cells $>50$ were scored as colonies [29].

\subsubsection{Analysis of Apoptosis}

The PANC-1 cells were seeded in 6-well plates $\left(2 \times 10^{5} /\right.$ well). After $24 \mathrm{~h}$ of incubation, the cells were treated with compound $12(0,5,10,20 \mu \mathrm{M})$ for $72 \mathrm{~h}$. After being harvested and washed with PBS, PANC-1 cells were stained with Annexin V/PI for $15 \mathrm{~min}$. Finally, the cells were detected and analyzed by flow cytometry.

\subsubsection{Hoechst 33258 Staining}

The PANC-1 cells were seeded in 6-well plates $\left(2 \times 10^{5} /\right.$ well $)$. After $24 \mathrm{~h}$ of incubation, the cells were treated with compound $12(0,5,10,20 \mu \mathrm{M})$ for $72 \mathrm{~h}$. Next, the cells were stained with Hoechst dye 33258 for five min at room temperature and assessed by a fluorescence microscopy.

\subsubsection{Analysis of Cell Cycle}

The PANC-1 cells were seeded in 6-well plates $\left(2 \times 10^{5} /\right.$ well). After $24 \mathrm{~h}$ of incubation, the cells were treated with varying concentrations of compound $12(0,5,10,20 \mu \mathrm{M})$ for $72 \mathrm{~h}$. After fixed in cold $75 \%$ ethanol at $-20{ }^{\circ} \mathrm{C}$ overnight, the cells were washed twice with PBS and stained with a PI solution containing $20 \mu \mathrm{g} / \mathrm{mL}$ of RNaseA and $50 \mu \mathrm{g} / \mathrm{mL}$ of PI for $30 \mathrm{~min}$. Finally, the cells were detected and analyzed by flow cytometry.

\subsubsection{Measurement of Intracellular ROS}

The PANC- 1 cells were seeded in 6 -well plates $\left(2 \times 10^{5} /\right.$ well). After $24 \mathrm{~h}$ of incubation, the cells were treated with varying concentrations of compound $12(0,5,10,20 \mu \mathrm{M})$ for $72 \mathrm{~h}$. After being stained with $10 \mu \mathrm{M}$ of DCFH-DA at $37^{\circ} \mathrm{C}$ for $30 \mathrm{~min}$, the cells were washed with media and were detected and analyzed by flow cytometry.

\subsubsection{Western Blot Analysis}

PANC-1 cells were harvested and seeded in 6-cell plates and allowed to settle overnight. Cells were treated with compound $\mathbf{1 2}(0,5,10$ and $20 \mu \mathrm{M})$ for $72 \mathrm{~h}$. Proteins were harvested and separated by SDS-PAGE and transferred onto PVDF membranes. Membranes were blocked in a blocking solution (containing $5 \%$ non-fat milk) and subsequently probed with primary antibodies at $4{ }^{\circ} \mathrm{C}$ overnight. After $15 \mathrm{~min}$ washes in TBST, the membranes were incubated with a secondary antibody for $1 \mathrm{~h}$ at room temperature. Antibodies against Bcl-2, Bax, PARP, Cleaved-Caspase-3, phosphorylation-Akt, Akt and GAPDH were purchased from Cell Signaling Technology (Beverly, MA, USA). Phosphorylation-PI3K and PI3K were purchased from Abcam (Cambridge, UK). The anti-mouse IgG and anti-rabbit secondary antibodies raised from goat were obtained from Abcam (Cambridge, UK). The bands were detected using an enhanced chemiluminescence system BeyoECL Plus (Beyotime, Nanjing, China).

\section{Conclusions}

In the present study, eighteen metabolites, including one new pyrone derivative (1), were identified from the culture of an algae-derived endophytic fungus Aspergillus sp. XNM-4. Among them, compounds 1, 17, and 18 were first reported from the genus Aspergillus. The pharmacological experiments showed that dimeric naphthopyrones $7, \mathbf{1 0}$, and especially $\mathbf{1 2}$, possessed potent cytotoxicity on five human cancer cell lines (PANC-1, A549, MDA-MB-231, Caco-2, and SK-OV-3), and one human normal cell line (HL-7702). Further studies indicated that compound 12 induced apoptosis, arrested 
the cell cycle at the G0/G1 phase in PANC-1 cells, caused morphological changes and generated ROS. Mechanism studies found that compound 12 induced PANC-1 apoptosis was via ROS-mediated PI3K/Akt signaling pathway. These experimental results may be beneficial for the development of naturally occurring dimeric naphthopyrones as anti-tumor agents.

Supplementary Materials: The following are available online at http://www.mdpi.com/1660-3397/17/4/207/s1, including the HPLC, UV, IR, HRESIMS, 1D NMR, HSQC, and HMBC spectra for compound 1, the HPLC, HRESIMS and 1D NMR spectra for compounds 2-18, and the ECD calculation for compounds 1 and 12.

Author Contributions: This paper was written by K.X. and C.G., and they contributed equally to this work. S.G. isolated the fungus Aspergillus sp. XNM-4 from Leathesia nana, while J.M. and H.T. identified and cultivated it. K.X. purified the secondary metabolites and defined their structures. C.G. tested their cytotoxic effects in vitro. D.S. approved the final version.

Funding: This research was supported by the National Natural Science Foundation of China (81803375), National Postdoctoral Program for Innovative Talents (BX201700247), China Postdoctoral Science Foundation (2018M630804), Natural Science Foundation of Shandong Province (ZR2016DQ07), and Shandong Provincial Natural Science Foundation for Distinguished Young Scholars (JQ201722).

Conflicts of Interest: The authors declare no conflict of interest.

\section{References}

1. Bugni, T.S.; Ireland, C.M. Marine-derived fungi: A chemically and biologically diverse group of microorganisms. Nat. Prod. Rep. 2004, 21, 143-163. [CrossRef] [PubMed]

2. Rateb, M.E.; Ebel, R. Secondary metabolites of fungi from marine habitats. Nat. Prod. Rep. 2011, 28, 290-344. [CrossRef]

3. Kjer, J.; Debbab, A.; Aly, A.H.; Proksch, P. Methods for isolation of marine-derived endophytic fungi and their bioactive secondary products. Nat. Protoc. 2010, 5, 479-490. [CrossRef]

4. Uzma, F.; Mohan, C.D.; Hashem, A.; Konappa, N.M.; Rangappa, S.; Kamath, P.V.; Singh, B.P.; Mudili, V.; Gupta, V.K.; Siddaiah, C.N.; et al. Endophytic fungi-alternative sources of cytotoxic compounds: A review. Front. Pharmacol. 2018, 9, 309-345. [CrossRef]

5. Corinaldesi, C.; Barone, G.; Marcellini, F.; Dell'Anno, A.; Danovaro, R. Marine microbial-derived molecules and their potential use in cosmeceutical and cosmetic products. Mar. Drugs 2017, 15, 118. [CrossRef]

6. Debbab, A.; Aly, A.H.; Proksch, P. Endophytes and associated marine derived fungi-ecological and chemical perspectives. Fungal Diversity 2012, 57, 45-83. [CrossRef]

7. Schulz, B.; Boyle, C.; Draeger, S.; Römmert, A.K.; Krohn, K. Endophytic fungi: A source of novel biologically active secondary metabolites. Mycol. Res. 2002, 06, 996-1004. [CrossRef]

8. Strobel, G.; Daisy, B.; Castillo, U.; Harper, J. Natural products from endo-phytic microorganisms. J. Nat. Prod. 2004, 67, 257-268. [CrossRef]

9. Zhang, P.; Li, X.M.; Wang, B.G. Secondary metabolites from the marine algal-derived endophytic fungi: chemical diversity and biological activity. Planta Med. 2016, 82, 832-842. [CrossRef] [PubMed]

10. Chen, X.Y.; Han, J.X.; Liu, Y.S.; Hajiakber, A.; Yuan, T. Chemical constituents from traditional Uighur herbal medicine Elaeagnus angustifolia flowers. China J. Chin. Mater. Med. 2018, 43, 1749-1753.

11. Huang, Z.J.; Shao, C.L.; Chen, Y.G.; She, Z.G.; Lin, Y.C. Pyrones in metabolites of marine mangrove endophytic fungus(No. ZZF79) from the South China Sea. Acta Sci. Nat. Univ. Sunyatseni. 2007, 46, 113-115.

12. Zhan, J.; Gunaherath, G.M.; Wijeratne, E.M.; Gunatilaka, A.A. Asperpyrone D and other metabolites of the plant-associated fungal strain Aspergillus tubingensis. Phytochemistry 2007, 68, 368-372. [CrossRef]

13. Akiyama, K.; Teraguchi, S.; Hamasaki, Y.; Mori, M.; Tatsumi, K.; Ohnishi, K.; Hayashi, H. New dimeric naphthopyrones from Aspergillus niger. J. Nat. Prod. 2003, 66, 136-139. [CrossRef]

14. Priestap, H.A. New naphthopyrones from Aspergillus fonsecaeus. Tetrahedron 1984, 40, 3617-3624. [CrossRef]

15. Li, D.H.; Han, T.; Guan, L.P.; Bai, J.; Zhao, N.; Li, Z.L.; Wu, X.; Hua, H.M. New naphthopyrones from marine derived fungus Aspergillus niger 2HLM-8 and their in vitro antiproliferative activity. Nat. Prod. Res. 2016, 30, 1116-1122. [CrossRef] [PubMed]

16. Bouras, N.; Mathieu, F.; Coppel, Y.; Lebrihi, A. Aurasperone F-a new member of the naphthogamma -pyrone class isolated from a cultured microfungus, Aspergillus niger C-433. Nat. Prod. Res. 2005, 19, 653-659. [CrossRef] [PubMed] 
17. Huang, H.B.; Xiao, Z.E.; Feng, X.J.; Huang, C.H.; Zhu, X.; Ju, J.H.; Li, M.F.; Lin, Y.C.; Liu, L.; She, Z.G. Cytotoxic naphtho- $\gamma$-pyrones from the mangrove endophytic fungus Aspergillus tubingensis (GX1-5E). Helv. Chim. Acta 2011, 94, 1732-1740. [CrossRef]

18. Zhang, Y.; Zhu, T.; Fang, Y.; Liu, H.; Gu, Q.; Zhu, W. Carbonarones A and B, new bioactive $\gamma$-Pyrone and $\alpha$-Pyridone derivatives from the marine-derived fungus Aspergillus carbonarius. J. Antibiot. 2007, 60, 153-157. [CrossRef] [PubMed]

19. Ding, G.; Jiang, L.; Guo, L.; Chen, X.; Zhang, H.; Che, Y. Pestalazines and Pestalamides, bioactive metabolites from the plant pathogenic fungus Pestalotiopsis theae. J. Nat. Prod. 2008, 71, 1861-1865. [CrossRef]

20. Guo, Y.X.; Lin, Z.M.; Wang, M.J.; Dong, Y.W.; Niu, H.M.; Young, C.Y.; Lou, H.X.; Yuan, H.Q. Jungermannenone A and B induce ROS- and cell cycle-dependent apoptosis in prostate cancer cells in vitro. Acta Pharmacol. Sin. 2016, 37, 814-824. [CrossRef]

21. Li, Z.; Qin, B.; Qi, X.; Mao, J.; Wu, D. Isoalantolactone induces apoptosis in human breast cancer cells via ROS-mediated mitochondrial pathway and downregulation of SIRT1. Arch. Pharmacal Res. 2016, 39, 1441-1453. [CrossRef]

22. Zhang, J.X.; Wang, X.L.; Vikash, V.; Ye, Q.; Wu, D.D.; Liu, Y.L.; Dong, W.G. ROS and ROS-mediated cellular signaling. Oxid. Med. Cell. Longevity 2016, 2016, 4350965. [CrossRef]

23. Jiang, Y.; Wang, X.Q.; Hu, D.D. Furanodienone induces G0/G1 arrest and causes apoptosis via the ROS/MAPKs-mediated caspase-dependent pathway in human colorectal cancer cells: A study in vitro and in vivo. Cell Death Dis. 2017, 8, 2815-2828. [CrossRef]

24. Hanahan, D.; Weinberg, R.A. Hallmarks of cancer: the next generation. Cell 2011, 144, 646-674. [CrossRef]

25. Gibson, C.J.; Davids, M.S. BCL-2 antagonism to target the intrinsic mitochondrial pathway of apoptosis. Clin. Cancer Res. 2015, 21, 5021-5029. [CrossRef]

26. Ghosh, S.; Sarkar, A.; Bhattacharyya, S.; Sil, P.C. Silymarin Protects mouse liver and kidney from thioacetamide induced toxicity by scavenging reactive oxygen species and activating PI3K-Akt pathway. Front. Pharmacol. 2016, 7, 481-495. [CrossRef]

27. Zhao, Y.; Wang, X.P.; Sun, Y.; Zhou, Y.X.; Yin, Y.H.; Ding, Y.X.; Li, Z.Y.; Guo, Q.L.; Lu, N. LYG-202 exerts antitumor effect on PI3K/Akt signaling pathway in human breast cancer cells. Apoptosis 2015, 20, 1253-1269. [CrossRef]

28. Guo, C.L.; Wang, L.J.; Zhao, Y.; Liu, H.; Li, X.Q.; Jiang, B.; Luo, J.; Guo, S.J.; Wu, N.; Shi, D.Y. A novel bromophenol derivative BOS-102 induces cell cycle arrest and apoptosis in human A549 lung cancer cells via ROS-mediated PI3K/Akt and the MAPK signaling pathway. Mar. Drugs 2018, 16, 43. [CrossRef]

29. Wang, L.J.; Guo, C.L.; Li, X.Q.; Wang, S.Y.; Jiang, B.; Zhao, Y.; Luo, J.; Xu, K.; Liu, H.; Guo, S.J.; et al. Discovery of novel bromophenol hybrids as potential anticancer agents through the ROS-mediated apoptotic pathway: Design, synthesis and biological evaluation. Mar. Drugs 2017, 15, 343. [CrossRef] 